\title{
PERLINDUNGAN HAK PENYANDANG DISABILITAS TUNA GRAHITA SEBAGAI SAKSI KORBAN DALAM PROSES PERADILAN PIDANA DI INDONESIA
}

\author{
Aah Laelatul Barkah \\ Fakultas Syariáh dan Hukum UIN Sunan Gunung Djati Bandung \\ Email: laelatulbarkahaah@gm ail.com
}

\begin{abstract}
Abstrak
Setiap orang yang lahir di dunia tidak sama, ada yang dilahirkan sempurna dan ada yang kurang sempurna atau disebut sebagai penyandang disabilitas. Salah satunya adalah tuna grahita atau retardasi mental. Dengan perkembangan otak yang kurang sempurna, penyandang disabilitas jenis ini cenderung mudah menjadi objek kejahatan. Permasalahan muncul ketika mereka diharuskan untuk menjadi saksi korban atas tindak kejahatan yang mereka alami mengingat keterbatasan yang mereka miliki. Tulisan ini menjabarkan bentuk perlindungan bagi penyandang disabilitas dengan melakukan analisis deskriptif terhadap Undang-undang Nomor 8 Tahun 2016 tentang Penyandang Disabilitas sebagai payung hukum pemerintah Indonesia dalam menjamin perlindungan bagi para penyandang disabilitas. Peradilan pidana atas kejahatan yang menimpa penyandang disabilitas dilakukan sebagaimana proses peradilan pidana pada umumnya. Yang membedakannya adalah saksi korban didampingi oleh seorang ahli selama persidangan.
\end{abstract}

\section{Kata Kunci: \\ Perlindungan, Disabilitas, Proses Peradilan}

\section{Pendahuluan}

Penyandang disabilitas memiliki kedudukan yang lemah baik di lingkungan keluarga sendiri maupun masyarakat. Lemahnya kedudukan penyandang disabilitas sering menghalangi mereka untuk berpartisipasi dalam berbagai hal di lingkungan masyarakat. Keterbatasan fisik, mental, intelektual dan sensorik adalah yang menjadi kendala utama. Penyandang disabilitas sering mendapat perlakuan diskriminatif, pengucilan dan bahkan pelecehan. Fakta yang tidak dapat dipungkiri bahwa penyandang disabilitas sering menjadi objek 
pelecehan seksual dan kekerasan. Berikut adalah Data Kasus Kekerasan sepanjang Tahun 2016 di wilayah Polda Jawa Barat:

Tabel 1.1 Data Kekerasan Terhadap Anak tahun 2016

\begin{tabular}{|c|c|c|c|c|c|c|c|c|}
\hline \multirow{3}{*}{ 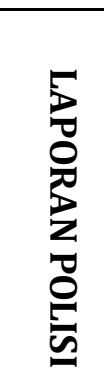 } & \multicolumn{3}{|c|}{$\begin{array}{c}\text { IDENTIFIKASI } \\
\text { KORBAN }\end{array}$} & \multicolumn{5}{|c|}{$\begin{array}{c}\text { IDENTIFIKASI TINDAK } \\
\text { PIDANA }\end{array}$} \\
\hline & \multirow[b]{2}{*}{ 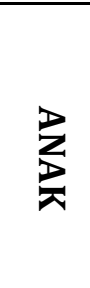 } & \multirow[b]{2}{*}{ 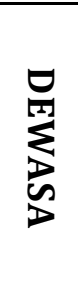 } & \multirow[b]{2}{*}{ 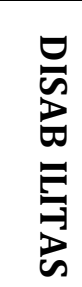 } & \multirow[b]{2}{*}{ 武 } & \multirow[b]{2}{*}{$\stackrel{\vec{s}}{\overline{\mathbf{x}}}$} & \multirow[b]{2}{*}{ 甭 } & \multicolumn{2}{|c|}{ EKSPLOITAS } \\
\hline & & & & & & & 陉 & 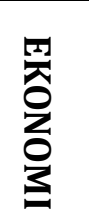 \\
\hline 1450 & 936 & 611 & 8 & 400 & 18 & 317 & 33 & 10 \\
\hline
\end{tabular}

(Sumber : Data Polda Penanganan Perkara Kekerasan Tahun 2016)

Data di atas, yang diperoleh dari POLDA Jawa Barat, menunjukkan bahwa penyandang disabilitas mengalami berbagai bentuk kekerasan mulai dari fisik, psikis, dan seks, bahkan eksploitasi ekonomi dan seks.

Aneka bentuk diskriminasi terjadi di level keluarga, komunitas, aparat penegak hukum, bahkan negara. Faktanya banyak kasus kekerasan seksual bahkan pemerkosaan yang tidak diproses secara hukum, dengan alasan lemahnya bukti, minimnya aksesibilitas hukum bagi disabilitas, bahkan disabilitas dianggap tidak mampu memberikan kesaksian dalam proses peradilan.

Data statistik mengenai jumlah penyandang disabilitas di dunia merupakan salah satu potret yang menunjukkan betapa isu disabilitas penting untuk dijadikan agenda bersama. Disabled Peoples' International Asia Pasific (DPIAP) menyebutkan lebih dari 665 juta orang di dunia adalah orang dengan disabilitas.Artinya lebih dari $15 \%$ dari populasi dunia menyandang disabilitas. PBB mencatat ada sekitar 60\% dari 650 orang dengan disabilitas di seluruh dunia tinggal di kawasan Asia dan Pasifik. UN Department of Economic and Social Affairs dalam lembar infonya menyebutkan 80 persen orang dengan disabilitas hidup di pedesaan dengan kondisi miskin (Buletin Difabel Sapda Jogja 2010). ${ }^{1}$

${ }_{1}$ Kebijakan pelayanan kesehatan reproduksi bagi perempuan penyandang disabilitas dalam rangka pencegahan kekerasan seksual (PDF Download Available). Di unduh dari: https://www.researchgate. net/publication/307612344 Kebijakan 
Di Indonesia, mendapati jumlah pasti orang dengan disabilitas bukanlah perkara mudah. Kementerian Sosial memperkirakan sebesar 3,11\%, sedangkan menurut data Kementerian Kesehatan jumlahnya 6\%. Data BPS menyebutkan penduduk difabel di Indonesia sebanyak 2.126.785. Selain itu, paradigma malu dan aib bila ada anggota keluarga menyandang disabilitas membuat pihak keluarga cenderung menutupi kenyataan tersebut dari publik, dan menutup akses bagi pendataan.Catatan WHO melaporkan bahwa rata-rata $10 \%$ dari jumlah penduduk di negara-negara berkembang termasuk Indonesia mengalami disabilitas. Maka Indonesia yang jumlah penduduknya sekarang mencapai 200 juta orang, sekitar 20 juta orang penduduknya adalah difabel. Apabila mengacu perbandingan laki-laki perempuan (1:3) maka kira-kira akan terdapat angka 13,7 juta orang perempuan disabilitas .2

Bagi perempuan yang hidup dengan disabilitas, bentuk diskriminasi dan kekerasan yang mereka alami menjadi berlapis. Artinya diskriminasi dan kekerasan yang mereka alami tidak hanya karena mereka adalah penyandang disabilitas, tapi juga karena identitas mereka sebagai perempuan, yang sebagian besar dari mereka hidup dengan kemiskinan.Kemiskinan dan disabilitas merupakan dua hal yang saling terkait bagaikan sebuah siklus. Kemiskinan membuat orang miskin beresiko mengalami difabilitas karena kekurangan nutrisi, tidak adanya layanan kesehatan yang memadai, minimnya akses dan informasi terkait dengan seksualitas dan kesehatan reproduksi.

Menurut Data dan Informasi Kemiskinan yang dipublikasi oleh Badan Pusat Statistik-Jakarta, bahwa jumlah penduduk miskin di Indonesia pada September 2011 sebesar 29,89 juta orang (12,36\%) dibandingkan dengan penduduk miskin pada Maret 2011 yang berjumlah 30,02 juta (12,49\%), jumlah penduduk miskin berkurang 0,13 juta orang selama enam bulan tersebut. Selama periode Maret 2011-September 2011, penduduk miskin di daerah perkotaan dan perdesaan masing-masing turun $0,14 \%$ dan $0,13 \%$.

Pada periode tersebut, penduduk miskin di daerah perkotaan berkurang 0,09 juta orang, sementara di daerah perdesaan berkurang 0,04 juta orang. Persentase penduduk miskin antara daerah

pelayanan kesehatan reproduksi bagi perem puan penyandang disabilitas dalam rangka pencegahan_kekerasan_seksual [di akses pada 12 Januari 2018 pukul:1.41 WIB].

${ }^{2}$ Ibid. 
perkotaan dan perdesaan tidak banyak berubah dari Maret 2011 ke September 2011. Pada Maret 2011, sebagian besar $(15,72 \%)$ penduduk miskin berada di daerah perdesaan. Begitu juga pada September 2011, yaitu sebesar 15,59\%. Dilihat dari jumlah penduduk, sebagian besar penduduk miskin berada di Pulau Jawa $(16,74$ juta orang). (Badan Pusat Statistik 2011).

Penyandang disabilitas memiliki potensi menjadi korban kejahatan sebanyak 4-10 lebih banyak dibandingkan orang yang dianggap "normal". Pada sistem peradilan pidana, seringkali penyandang disabilitas menemukan diskriminasi oleh Aparat Penegak Hukum (APH). Pusham UII (2015) mencatat ada beberapa kasus yang melibatkan penyandang disabilitas mental tidak diselesaikan oleh penyidik. Alasan utamanya karena sulitnya komunikasi antara penyidik dengan penyandang disabilitas.

Perlindungan hukum merupakan suatu bentuk pelayanan yang wajib diberikan oleh pemerintah untuk memberikan rasa aman kepada setiap warga masyarakat.Perlindungan hukum bukan hanya diperuntukan bagi orang yang normal saja bahkan penyandang disabilitas pun mempunyai hak keadilan dan perlindungan hukum. Hak perlindungan hukum ini terangkum dalam Pasal 9 UU Penyandang disabilitas.

Upaya perlindungan hukum bagi penyandang disabilitas seharusnya diperhatikan lebih intens, karena seperti yang diketahui untuk penyandang disabilitas ini agak kesulitan dalam berinteraksi karena kendala inilah banyak kasus dari penyandang disabilitas tidak diproses dengan baik dengan alasan bahwa saksi korban tidak dapat memberikan keterangan untuk kesaksian. ${ }^{3}$

Semua penegak hukum seharusnya menyadari bahwa akses terhadap keadilan harusdinikmati oleh semua orang dan tidak ada pengecualian ataupun diskriminasi. Undang Undang Dasar (UUD) 1945, Undang-Undang Kekuasaan Kehakiman, dan lain-lain peraturan perundang-undangan di bidang perlindungan hak selalu menegaskan perlakuan sama dan adil bagi semua warga Negara. Semua perangkat itu menunjukan persamaan di depan hukum (equality before the law). Tetapi jika hukum, dalam praktiknya belum dapat

${ }^{3}$ Wahyu Wagiman, dkk, Naskah Akademis dan Rancangan Peraturan Pemerintah Tentang Pemberian Kompensasi dan Resituasi serta Bantuan Bagi Korban.Jakarta. ICW. 2007.hlm. 9 
menerapkan hal tersebut maka prinsip keadilan di depan harus lebih di tegaskan kembali dengan mengutamakan hak-hak dari setiap warga Negara. ${ }^{4}$

Tidak dapat dipungkiri kaum disabilitas di Indonesia dari tahun ke tahun mengalami peningkatan kuantitasnya. Berdasarkan data Sensus Nasional Biro Pusat Statistik ada lebih banyak perempuan penyandang disabilitas dibandingkan yang laki-laki $(52,7 \%$ berbanding 47,3\%). Dengan demikian peluang kaum disabilitas menjadi korban tindak pidana cukup besar. Hal itulah yang menjadi pencetus terjadinya kekerasan terhadap perempuan disabilitas. ${ }^{5}$

Permasalahan muncul ketika seorang penyandang disabilitas diharuskan untuk menjadi saksi korban dalam proses peradilan pidana. Seringkali penyandang disabilitas mengalami berbagai hambatan dan kesulitan dalam memberikan kesaksian, salah satunya ketika penyandang disabilitas diragukan kesaksiannya oleh aparat penegak hukum.

Sebagai contoh yaitu kasus pelecehan seksual terhadap penyandang tuna grahita yang terjadi di Kuningan. dimana aparat kepolisian kesulitan meminta keterangan saksi korban. Dalam memberi keterangan saksi korban sering mengubah keterangannya. Aparat penegak hukum sempat akan menyerah, akan tetapi karena adanya bukti visum dan barang bukti lainnya menjadikan aparat penegak hukum melanjutkan kasus ini. Hampir saja si pelaku terlepas dari jeratan hukum akibataparat penegak hukum kurang memahami permasalahan disabilitas, kategorisasi disabilitas, serta kebutuhan mendasar penyandang ketika menjadi saksi korban suatu tindak pidana.

Padahal pada Pasal 2 huruf c Undang-undang Nomor 8 Tahun 2016 tentang Penyandang Disabilitas (UU Penyandang Disabilitas) menyebutkan pelaksanaan dan pemenuhan hak-hak penyandang disabilitas berasaskan Tanpa Diskriminasi. Pasal tersebut dengan tegas menyatakan bahwa hak penyandang disabilitas sama dengan manusia normal lainnya tanpa harus ada diskriminasi. Dalam hal ini pun perlu ditegaskan bahwa disabilitas mempunyai kedudukan yang setara di hadapan hukum dan memiliki hak atas akses yangsama

${ }^{4}$ Amad sudiro, dkk, Hukum dan Keadilan (aspek nasional \& internasional), Jakarta. PT.Rajagrafindo Persada, 201.Hlm. 121

${ }^{5}$ Badan Pusat Statistik, Diunduh pada tanggal : 25 Oktober 2017 pukul 15.17 WIB 
terhadap peradilan. Pasal 35 UU Penyandang disabilitas menyebutkan bahwa: "Proses peradilan Pidana bagi Penyandang Disabilitas dilaksanakan sesuai dengan ketentuan hukumacara pidana".

Dalam hal ini dapat lebih ditegaskan bahwa sebenarnya dalam proses peradilan pidana penyandang disabilitas seharusnya disesuai kan dengan Kitab Undang Undang Hukum Acara Pidana (KUHAP), hanya saja dalam proses peradilan pidana penyandang disabilitas ini harus disertai dengan fasilitas pendukung kebutuhan penyan dang disabilitas. Dalam UU Penyandang Disabilitas tertulis hak-hak penyandang disabilitas yang telah dituangkan sedemikian rupa. Namun sayangnya kebijakan akan Undang-Undang tersebut belum diimplementasikan dengan baik di Indonesia. Proses peradilan pidana seharusnya lebih memperhatikan pemenuhan hak-hak atas penyandang disabilitas tersebut.

Akses terhadap hukum yang berkeadilan masih sangat langka dirasakan bagi komunitas disabilitas, terutama bagi perempuan penyandang disabilitas.

\section{Perlindungan Hak Penyandang Disabilitas Tuna Grahita Sebagai Saksi Korban dalam Proses Peradilan Pidana Di Indonesia}

Proses Peradilan pidana dilakukan sesuai Kitab Undang-Undang Hukum Acara Pidana (KUHAP) sebagai aturan hukum yang berlaku untuk proses peradilan pidana bagi semua orang tanpa terkecuali. Dalam hal ini muncul pendapat bahwa proses peradilan pidana bagi penyandang disabilitas harus dipisahkan. Namun pasal 35 UU Penyadang Disabilitas menyatakan bahwa proses peradilan pidana bagi penyandang disabilitas berjalan sesuai ketentuan KUHAP.

Indonesia merupakan salah satu negara yang cukup mengakomodir perlindungan terhadap hak-hak bagi penyandang disabilitas. Perlindungan hak penyandang disabilitas dalam tulisan ini dilatarbelakangi oleh keinginan melindungi hak-hak terhadap penyandang disabilitas khususnya tuna grahita oleh keterlibatannya dengan sistem peradilan pidana di Indonesia sebagai saksi korban. Teori persamaan di hadapan hukum menjadi kendaraan untuk penerapan hukum yang adil, dalam lingkup ini lebih difokuskan pada aspek 
peraihan hak dari penyandang disabilitas yang tertuang dalam UU Penyandang Disabilitas.

Pasal 28 sampai dengan Pasal 35. menjadi landasan pelaksanaan hak penyandang disabilitas, termasuk di dalamnya Ppenanganan lembaga yang memiliki kewenangan melakukan proses peradilan pidana sudah sesuai dengan peraturan perundang-undangan yang berlaku, seperti KUHAP, KUHP, sampai dengan standar prosedur operasional (SOP). Meski demikian masih saja terdapat hambatan dalam pelaksanaan hak penyandang disabilitas, khususnya tuna grahita sebagai saksi korban.

Pemerintah dan pemerintah daerah wajib menjamin dan melindungi hak penyandang disabilitas sebagai subjek hukum untuk melakukan tindakan hukum yang sama dengan yang lainnya. Dalam hal ini penegak hukum yang terlibat dalam proses peradilan pidana yang meliputi POLRI, Kejaksaan Negeri dan Pengadilan Negeri, yang termasuk dalam kualifikasi lembaga pemerintahan, telah melakukan perlindungan hak penyandang disabilitas meski tidak berpatokan pada pasal 28 tersebut, bahkan cenderung memperlakukan mereka sama seperti orang pada umumnya.

Dalam pasal 29 tercantum bahwa Pemerintah dan pemerintah daerah wajib menyediakan bantuan hukum kepada penyandang disabilitas dalam setiap pemeriksaan pada setiap lembaga penegak hukum dalam hal keperdataan dan/atau pidana sesuai dengan ketentuan peraturan perundang-undangan. Ketentuan tersebut sudah terlaksanakan dengan adanya bantuan hukum bagi penyandang disabilitas. Penegak hukum dalam pemeriksaan sudah menyediakan bantuan hukum dalam bentuk memproses kejahatan yang dilakukan terhadap penyandang disabilitas, meskipun dalam hal ini POLRI, Kejaksaan dan Pengadilan Negeri baru mengetahui akan adanya UU Penyandang Disabilitas, mereka tetap menyediakan bantuan hukum terhadap setiap orang termasuk penyandang disabilitas ini. ${ }^{6}$

Dari data tindak pidana kekerasan terhadap anak dan perempuan yang terjadi di wilayah hukum POLDA Jawa Barat tahun 2016, terdapat 8 kasus kekerasan terhadap penyandang disabilitas dari

${ }^{6}$ Wawancara dengan Jumadi Apri Ahmad,S.H.,M.H. (Hakim Pengadilan Kab .Cirebon Sumber), Jum'at, 9 Februari 2018 Pkl: 11.15 WIB 
keseluruhan 1450 kasus. Sedangkan di tahun 2017 dari bulan Januari sampai bulan Mei terdapat 1 kasus dari 770 kasus. ${ }^{7}$

Data di atas belum termasuk fakta bahwa seringkali masih ada penyandang disabilitas tidak menyadari bahwa dirinya telah menjadi korban kekerasan begitupun orang tuanya yang lebih memilih tidak melaporkan kekerasan tersebut ke polisi karena takut kejadian tersebut akan tersebar dan akan menjadi aib keluarga. Berdasarkan hasil observasi yang dilakukan oleh penulis di tahun 2017, diketahui bahwa perlindungan hak penyandang disabilitas tuna grahita sebagai saksi korban dalam proses peradilan pidana khususnya di lingkungan pengadilan Kuningan, mulai dari proses penangkapan sampai selesai sudah sesuai dengan SOP yang ada. Untuk penanganan saksi korban yang mengalami tindak pidana kekerasan ditangani sesuai keadaan yang ada. Salah satu contoh yang sering dilakukan bahwa setiap yang menjadi saksi akan dilayani sesuai dengan kebutuhan dari saksi tersebut. Salah satu yang sering terjadi adalah ketika ada saksi korban yang mengalami depresi karena kekerasan, pihak Polres melayani dengan lemah lembut meskipun tanpa didampingi oleh ahli.8

Memang tidak ada hal khusus yang dilakukan oleh pihak penyidik dalam melaksanakan kewajibannya untuk menyidik, semua berpatokan kepada peraturan Undang-Undang dan KUHAP yang ada. Tetapi dalam hal perlindungan hak penyandang disabilitas seharusnya sesuai dengan UU Penyandang Disabilitas karena di dalam undang-undang tersebut sudah diatur mengenai hak-hak penyandang disabilitas apabila berkenaan dengan hukum. Dalam Pasal 30 ayat (1) UU Penyandang Disabilitas menjelaskan bahwa penegak hukum sebelum memeriksa penyandang disabilitas wajib meminta pertimbangan atau saran dari dokter, psikolog dan pekerja sosial.

Dari isi pasal tersebut seharusnya penegak hukum meminta pertimbangan atau saran dari ahli bertujuan untuk mengetahui apakah saksi korban penyandang disabilitas sehat akalnya dan dapat memberikan keterangan sebagaimana mestinya, dan saksi korban mengalami kelainan atau tidak dalam hal fisik dan lain sebagainya, serta kemungkinan saksi korban mengalami kondisi psikososial atau tidak.

\footnotetext{
${ }^{7}$ Data dari Polisi Daerah (POLDA) Jawa Barat

${ }^{8}$ Wawancara dengan Brigadir Asep Bambang K (Penyidik PPA/Sat Reskrim Polres Kuningan), Selasa, 7 November 2017 Pkl: 11.00 WIB
} 
Oleh karenanya, saat pemeriksaan seharusnya menghadirkan pertimbangan atau saran ahli. Hal tersebut tidak diterapoan sebagaimana mestinya dikarenakan pihak Polres, Kejaksaan dan Pengadilan Negeri baru mengetahui akan adanya ketentuan tersebut.

Pendampingan yang dimaksud antara lain dilakukan pada saat Visum et Repertum oleh dokter atausebelum pemeriksaan untuk memastikan bahwa saksi korban secara psikologis siap untuk dimintai keterangan dalam waktu dekat. Jika saksi korban penyandang disabilitas adalah siswa/siswi dari sekolah luar biasa (SLB), selain didampingi oleh orang tua, dapat didampingi juga oleh guru. ${ }^{9}$

Dalam praktik biasanya ketika menangani kasus kekerasan terhadap perempuan dan anak pihak POLRI melakukan kerjasama dengan pihak seperti P2TP2A (Pusat Pelayanan Terpadu Pemberdayaan Perempuan dan Anak), Dinas Sosial, BAPPAS dan LPSK. Akan tetapi Penyidik PPA Polres Kuningan yang diwawancarai oleh penulis tidak melakukan kerjasama dengan P2TP2A dan LPSK dikarenakan belum dibuatnya lembaga tersebut oleh Pemerintah Daerah. Penyidik Polres hanya bekerjasama dengan Dinas sosial dan BAPPAS. Adapun penanganan kasus yang melibatkan penyandang disabilitas, penyidik bekerjasama dengan Dinas Sosial.

LPSK belum sampai ke kota/kabupaten karena pusatnya memang adanya di Jakarta, dengan demikian ada kemungkinan pihak Polres tidak melakukan kerjasama dengan LPSK dikarenakan tidak mengetahui kontak LPSK ataupun tidak mengetahui siapa yang harus dihubungi.10

Penanganan di Kejaksaan mulai dari masuknya tahap satu sampai selesai sudah sesuai dengan SOP yang ada. Untuk penanganan saksi korban yang mengalami tindak pidana kekerasan ditangani sesuai keadaan yang ada dan sesuai keinginan dari saksi tersebut. Salah satu contoh yang sedang ditangani bahwa setiap kali saksi korban penyandang tuna grahita dihadapkan dalam persidangan selalu ingin ditemani oleh pekerja sosial yang ada. Meskipun saksi korban merupakan siswa SLB Negeri Taruna Mandiri, namun ia merasa lebih nyaman dengan pekerja sosial di banding dengan keluarga dan gurunya.

\footnotetext{
${ }^{9}$ Wawancara dengan Suryaningsih,S.H.,M.H. (Kanit Perlindungan Perempuan dan Anak) Senin, 27 November 2017 Pkl: 14.23 WIB

10 Wawancara dengan Suryaningsih,S.H.,M.H. (Kanit Perlindungan Perempuan dan Anak) Senin, 27 November 2017 Pkl: 14.23 WIB
} 
Jaksa sendiri berpendapat bahwa ketidak inginan saksi korban penyandang disabilitas ini tidak mau ditemani oleh keluarganya adalah karena saksi korban ini merasa malu.11 Hal ini dapat menjadi titik fokus ketika seorang ahli memang sangat dibutuhkan untuk mendampingi dan memeriksa saksi korban terlebih dahulu.

Pada proses peradilan pidana, dalam praperadilan jaksa memeriksa kembali tersangka dan saksi-saksi begitupun barang bukti, tetapi jaksa merasa sudah yakin dengan laporan tahap satu yang diberikan penyidik meski pemeriksaan ulang korban dalam hal memberi kesaksian sering berubah-ubah. 12 .

Ketika di tahap praperadilan sudah dirasa yakin maka dibuatlah dakwaan. Penyandang disabilitas sudah didampingi oleh pekerja so sial, namun tidak ada pendampingan oleh dokter maupun psikologi karena dirasa tidak diperlukan karena tingkat disabilitas tuna grahita ringan. Saksi korban tersebut masih bisa diajak berkomunikasi, tidak memiliki kelainan lain, serta tidak menunjukkan gejala trauma.

Dalam kasus lain yang ditangani oleh jaksa, tidak dilakukan penanganan khusus bagi penyandang disabilitas tuna grahita, dengan alasan tidak diketahuinya undang-undang mengenai penyandang disabilitas ini.

Pada proses pengadilan, kesaksian penyandang disabilitas sering dipengaruhi oleh suasana hatinya, sehingga penegak hukum harus menuruti apapun yang diinginkannya. Bahkan pada saat sidang berjalan penyandang disabilitas ini hanya ingin ditemani oleh pihak pekerja sosial saja dan tidak ingin ditemani oleh orang tuanya. Setelah mengetahui adanya UU Penyandang Disabilitas ini, pihak penegak hukum merasa bahwa perlakuan khusus tersebut memang harus dilakukan sebagai bentuk penerapkannya.13pada praktiknya penanganan kasus bergantung pada kondisi, tetapi diakui bahwa penerapan Pasal 30 ini dapat membantu proses peradilan pidana. 14

\footnotetext{
14.00 WIB

12 Wawancara dengan Leni Herlina (Jaksa Fungsional di Kejaksaan Kuningan), Selasa, 9 Januari 2018 Pkl: 14.35 WIB

${ }_{13}$ Wawancara dengan Mila Gustiana (Jaksa Fungsional Kejaksaan Kuningan), Selasa, 9 Januari 2018 Pkl: 14.00 WIB

${ }^{14}$ Wawancara dengan Benny Harkat, S.H.,M.H. (Jaksa Fungsional Kejaksaan Kab. Cirebon Sumber), Jum'at, 9 Februari 2018 Pkl: 09.00 WIB
}

11 Wawancara dengan Mila Gustiana (Jaksa Fungsional) Selasa, 9 Januari 2018 Pkl: 
Ditambahkan dalam proses pengadilan seorang saksi ahli dapat dimintai pendapat dan menjelaskan situasi psikologi, kesehatan dan sosiologi korban.

Menurut salah satu hakim di lingkungan Pengadilan Negeri Kuningan, pemeriksaan korban, baik fisik maupun psikis bukanlah kewenangan pengadilan negeri, pengadilan negeri hanya bertugas mencari kebenaran saja. Dengan kata lain mengenai pemeriksaan pengadilan tidak tahu menahu oleh karenanya dikembalikan lagi kepada penyidik karena hakim hanya menerima jadi saja. Dengan demikian, dalam proses pengadilan tidak diperlukan pendampingan pertimbangan atau saran dari dokter, psikolog dan pekerja sosial. ${ }^{15}$

POLRI, Kejaksaan dan Pengadilan Negeri dalam melakukan pemeriksaan terhadap anak penyandang disabilitas mengizinkan orang tua atau keluarga, pendamping atau penerjemah untuk mendampingi anak penyandang disabilitas sesuai dengan Pasal 31 UU Penyandang Disabilitas dimana pasal tersebut mewajibkan penegak hukum untuk mengizinkan orang tua dan penerjemah untuk mendampingi. 16

Seyogyanya hakim menetapkan penyandang disabilitas tidak cakap hukum berdasarkan keterangan dari dokter maupun psikolog dan juga pekerja sosial, bukan semata-mata karena disabilitasnya saja, ${ }^{17}$ karena penyandang disabilitas memiliki taraf-taraf tertentu. Penyandang diasbilitas tuna grahita dapat digolongkan ke dalam tuna grahita taraf berat, sedang dan juga ringan.

Penyandang disabilitas tuna grahita ringan yaitu biasanya masih dapat diajak berkomunikasi, hanya saja dalam hal berfikir agak lamban. Adapun retardasi mental sedang, penyandang masih dapat diajak berkomunikasi juga tetapi dalam hal berbicara membutuhkan jeda untuk berfikir dulu atau memberikan keterangan yang berubahubah seperti kasus yang dijadikan contoh di atas. Ada pula retardasi mental berat, taraf ini memang tergolong lebih parah dari yang lainnya,

\footnotetext{
${ }^{15}$ Wawancara dengan Dicky Ramdhani, S.H. (Hakim di Pengadilan Negeri Kuningan) Selasa, 9 Januari 2018 Pkl: 11.00 WIB.

16 Wawancara dengan Dicky Ramdhani, S.H. (Hakim di Pengadilan Negeri Kuningan), Mila Gustiana (Jaksa Fungsional), dengan Brigadir Asep Bambang K (Penyidik PPA/Sat Reskrim Polres Kuningan) di waktu yang terlampir di surat keterangan wawancara.

17 Wawancara dengan Dicky Ramdhani, S.H. (Hakim di Pengadilan Negeri Kuningan) Selasa, 9 Januari 2018 Pkl: 11.00 WIB.
} 
sehingga ketika di pengadilan negeri menetapkan bahwa orang tersebut dinyatakan tidak cakap. 18

Pada Pengadilan Negeri Kuningan, pasal 33 UU tersebut belum pernah dilakukan, karena selain pihak pengadilan baru mengetahui UU Penyandang Disabilitas ini, juga dikarenakan belum ada kasus mengenai penyandang disabilitas dengan taraf yang berat. 19

Terkait dengan penjelasan sebelumnya mengenai penggolongan tingkat keparahan penyandang disabilitas sendiri ditegaskan pada Pasal 33 ayat 2 bahwa keterangan dokter, psikolog dan psikiater memang diperlukan. Berkaitan dengan ayat selanjutnya pun yaitu ayat 3 dan ayat 4 , pihak pengadilan tidak melarang mengenai kepentingan penyandang disabilitas itu sendiri baik untuk menunjuk orang mewakili penyandang disabilitas ketika ditetapkan tidak cakap.

Setidaknya terdapat 8 pasal dalam UU Penyandang Disabilitas yang membahas mengenai hak penyandang disabilitas dalam penegakan hukum. Selanjutnya Pasal 34 memperjelas lebih menjelaskan mengenai ketentuan pasal sebelumnya. Jikalau ada kasus yang seperti itu hakim sendiri pun akan menentukannya dengan melihat keterangan daridokter, psikolog dan psikiater. ${ }^{20}$

Mengacu pada alur proses peradilan pidana, tugas hakim terkait dengan perlindungan hak penyandang disabilitas sebagai saksi korban dalam proses peradilan pidana di Indonesia adalah menyempurnakan proses penegakan hukum dengan mencari kebenaran terhadap tindak pidana dan pemenuhan hak penyandang disabilitas. Diantaranya dengan memeriksa kembali berkas perkara, apakah saat BAP ada pendampingan atau tidak, atau pada saat sebelum dilakukan pembuatan BAP apakah penyidik memberikan hak penyan dang untuk mendapatkan pemeriksaan terlebih dahulu dari dokter, psikolog dan juga pekerja sosial serta mendapatkan pertimbangan atau saran terkait hasil pemeriksaan tersebut untuk kemudian dijadikan sebagai dasar dalam penegakan hukum.

Dalam persidangan, pemeriksaan proses peradilan pidana tidak terbatas pada BAP saja tetapi juga meliputi dakwaan dan pemeriksaan

\footnotetext{
18 Wawancara dengan Jumadi Apri Ahmad,S.H.,M.H. (Hakim Pengadilan Kab.Cirebon Sumber), Jum'at, 9Februari 2018 Pkl: 11.15 WIB

19 Wawancara dengan Jumadi Apri Ahmad,S.H.,M.H. (Hakim Pengadilan Kab.Cirebon Sumber),Jum'at, 9 Februari 2018 Pkl: 11.15 WIB

20 Wawancara dengan Jumadi Apri Ahmad,S.H.,M.H. (Hakim Pengadilan Kab.Cirebon Sumber), Jum'at, 9 Februari 2018 Pkl: 11.15 WIB
} 
alat bukti yang diberikan oleh jaksa. Maka disitulah peran hakim dalam hal penerapan perlindungan hak penyandang disabilitas sangatlah besar, karena menjadi penentu dalam memperbaiki kinerja penyidik dan jaksa adalah hakim. Bukan hanya dalam pemeriksaan berkas saja, seyogyanya dalam hal jalannya persidangan ketika saksi korban ditanya pun hakim meninjau terlebih dahulu apakah sudah ada pertimbangan atau saran terlebih dahulu dari dokter, psikolog maupun pekerja sosial terkait dengan kemampuan penyandang disabilitas dalam memberikan kesaksian.

Apabila dalam pemeriksaan berkas perkara maupun persidangan telah disertai pertimbangan atau saran dari dokter, psikolog dan pekerja sosial maka proses peradilan pidana telah berjalan dan memenuhi ketentuan Pasal 30 dan 31 UU Penyandang Disabilitas. Namun sayangnya terdapat ketidaksesuaian beberapa alur proses peradilan pidana, menjadikan tidak maksimalnya penerapan undang-undang meskipun pada akhirnya pemeriksaan kasus tetap berjalan.

Adapun mengenai pelaksanaan pasal 34 mengenai penetapan pengadilan terhadap kecakapan seorang penyandang disabilitas, tidak ditemukan di Pengadilan Kuningan, karena belum pernah menangani kasus demikian. Sehingga tidak dapat dinilai apakah mereka telah menerapkan ketentuan yang dimaksud atau tidak

Proses peradilan pidana bagi penyandang disabilitas pada pengadilan Negeri Kuningan dilaksanakan sesuai dengan ketentuan hukum acara pidana dan tidak ada perbedaan. Hakim Pengadilan Negeripun melaksanakan Proses Peradilan Pidana bagi Penyandang Disabilitas sesuai dengan KUHAP, semua itu sesuai dengan ketentuan dalam Pasal 35 Undang-Undang Nomor 8 Tahun 2016 tentang Penyandang Disabilitas.

Dengan demikian keseluruhan pemenuhan dari Pasal 28, Pasal 31, Pasal 32, Pasal 33, Pasal 34 dan juga Pasal 35 Undang-Undang Nomor 8 tahun 2016 tentang Penyandang Disabilitas telah sesuai dengan praktik. Namun ketidaktahuan Hakim Pengadilan Negeri Kuningan akan UU Penyandang Disabilitas menjadikan proses peradilan pidananya kurang maksimal. 


\section{Penutup}

Permasalahan terkait Perlindungan hak penyandang disabilitas tuna grahita sebagai saksi korban dalam proses peradilan pidana di Indonesia pada dasarnya sudah mempunyai aturan sendiri, yaitu pada Undang-Undang Nomor 8 Tahun 2016 tentang Penyandang Disabilitas pada Pasal 28, Pasal 29, Pasal 30, Pasal 31, Pasal 32, Pasal 33, Pasal 34 dan Pasal 35. Dalam melakukan Proses Peradilan Pidana pihak Polres, Kejaksaan Negeri dan Pengadilan Negeri telah melakukan sebagaimana mestinya yang ada di dalam SOP masingmasing lembaga baik dalam pengamanan maupun pengolahan tempat kejadian perkara, pengamatan (observasi), wawancara (interview), tahap I, tahap II, Ekseskusi dan peradilannya. Tetapi dengan adanya Undang-Undang Nomor 8 Tahun 2016 tentang Penyandang Disabilitas ini seharusnya menjadi dasar dalam melindungi hak penyandang disabilitas khususnya dalam proses peradilan pidana di Indonesia.

Dalam penerapan aturan Undang-Undang Nomor 8 Tahun 2016 tentang Penyandang Disabilitas pada pada Pasal 28, Pasal 30, Pasal 31, Pasal 32, Pasal 33, Pasal 34 dan Pasal 35 tersebut masih banyak kendala untuk perlindungan hak penyandang disabilitas sesuai dengan undang-undang terutama dalam praktek di Polres, Kejaksaan Negeri dan Pengadilan Negeri Kuningan. Kendala tersebut antara lain berasal dari penyandang disabilitas, orang tua, pelaku serta tidak terdapat nya lembaga pendukung. Di samping itu, tidak tersosialisasikannya UU Nomor 8 Tahun 2016 tentang Penyandang Disabilitas di kalangan penegak hukum khususnya di Kabupaten Kuningan.

\section{DAFTAR PUSTAKA}

Amad Sudiro, dkk, 2014, Hukum dan Keadilan (aspek nasional \& internasional), Jakarta. PT.Rajagrafindo Persada.

Arif Gosita, 1993, Masalah Korban Kejahatan, Jakarta, Akademika Presindo.

Asyhabuddin, 2008, Difabilitas dan Pendidikan Inklusif: Kemungkinannya di STAIN Purwokerto, Jurnal Pemikiran AlternatifPendidikan Insania, Vol.13, No. 3. 
Barda Nawawi Arief, 1992, Bunga Rampai Hukum Pidana, Bandung, Alumni.

Dikdik M Arief Mansur dan Elisatris Gultom, 2007, Urgensi Perlindungan Korban Kejahatan: Antara Norma dan Realita, Jakarta, Raja Grafindo Persada.

E. Kosasih, 2012, Cara Bijak Memahami Anak Berkebutuhan Khusus, Bandung, Yrama Widya.

G. Widiartana, 2014, Viktimologi Perspektif Korban dalam Penanggulangan Kejahatan, Yogyakarta, Cahaya Atma Pustaka.

Hari Kurniawan, 2014, Kompleksitas Persoalan Difabel berhadapan dengan Hukum, Yogyakarta, SIGAB.

Hari Kurniawan, dkk, 2015, Aksesibilitas Peradilan Bagi Penyandang Disabilitas, Yogyakarta, PUSHAM UII.

Harjono, 2008, Konstitusi sebagai Rumah Bangsa, Jakarta, Sekertariat Jenderal dan Kepanitiaan Mahkamah Konstitusi.

Ishaq, 2009, Dasar-dasar Ilmu Hukum, Jakarta, Sinar Grafika.

Leden Marpaung, 2010, Proses Penanganan Perkara Pidana (di Kejaksaan \& Pengadilan Negeri Upaya Hukum \& Eksekusi), Jakarta, Sinar Grafika.

Lili Rasjidi dan B. Arief Sidharta, 1994, Filsafat Hukum Madzab dan Refleksi, Bandung, PT. Remaja Rosda Karya.

Mardjono Reksodiputro, 1993, Sistem Peradilan Pidana Indonesia (Melihat Kepada Kejahatan Dan Penegakan Hukum Dalam BatasBatas Toleransi), Jakarta, Fakultas Hukum Universitas Indonesia.

Mohammad Efendi, Pengantar Psikopedogogik Anak Berkelainan, Jakarta, Bumi Aksara.

Mohammad Taufik Makarao, 2010, Syhasril, Hukum Acara Pidana dalam Teori dan Praktek, Bogor, Ghalia Indonesia.

Muchsin, 2003, Perlindungan dan Kepastian Hukum bagi Investor di Indonesia, Surakarta, magister Ilmu Hukum Program Pascasarjana Universitas Sebelas Maret.

Muladi, 2005, HAM Dalam Perseptik Sistem Peradilan Pidana, Bandung, Refika Aditama.

Muladi, 1995, Kapita Selekta Sistem Peradilan Pidana, Semarang, Badan Penerbit Universitas Diponegoro.

M. Syafi'ie, Purwanti, Mahrus Ali, 2014, Potret Difabel Berhadapan dengan Hukum Negara, Yogyakarta, SIGAB. 
Noeng Muhajir, 2002, Metode Penelitian Kualitatif, Yogyakarta, Rake Sarasin.

Philipus M. Hadjon, 1987, Perlindungan Rakyat Bagi Rakyat di Indonesia (sebuah Studi tentang Prinsip-Prinsipnya, Penanganannya oleh Pengadilan Administrasi Negara), Surabaya, PT. Bina Ilmu.

Philipus M. Hadjon, 1987, Perlindungan Hukum Bagi Rakyat Indonesia, Surabaya, PT. Bina Ilmu.

Puguh Ari Wijayanto, 2013, Upaya Perlindungan Hukum Terhadap Kaum Disabilitas Sebagai Korban Tindak Pidana, Jurnal Hukum.

Romli Atmasasmita, 1996, Sistem Peradilan Pidana (Criminal Justice System) Perspektif Eksistensialisme Dan Abolisionalisme, Jakarta, Bina Cipta.

Ronny Hanitijo Soemitro, 2001, Metodologi Penelitian Hukum dan Jurimetri, Jakarta, Ghalia Indonesia.

S. Tanusubroto, S.H., Peranan Praperadilan Dalam Hukum Acara Pidana, Alumni, Bandung.

Satjipto Rahardjo, 2000, ilmu hukum, Bandung, PT.CITRAAditya Bakti. Satdjipto Rahardjo, 1983, Permasalahan Hukum di Indonesia, Bandung, Citra Aditya Bakti.

Setiono, 2004, Rule of Law (Supremasi Hukum), Surakarta, Magister Ilmu Hukum Program Pascasarjana Universitas Sebelas Maret.

Setiono, 2004, Rule of Law (Supremasi Hukum), Surakarta, Tesis Magister Ilmu Hukum Program Pascasarjana Universitas Sebelas Maret.

Siswanto Sunarso, 2012, Viktimologi dalam Sistem Peradilan Pidana, Jakarta Timur, Sinar Grafika.

Sudikno Mertokusumo, 2009, Penemuan Hukum, Bandung, Citra Aditya Bakti.

Sugiono, 2005, Memahami Penelitian Kualitatif, Bandung, Alfabeta.

Suryana, 2004, Terapi Autisma Anak Berbakat dan Anak Hiperaktif, Jakarta, Progress Jakarta.

Suryono Ekotama, ST. Harum Pudjianto, dan G. Wiratama, 2001, Abortus Provocatus Bagi Korban Perkosaan Perspektif Viktimologi, Kriminologi dan Hukum Pidana, Yogyakarta, Universitas Atma Jaya Yogyakarta.

Sutjahati Somantri, 2012, Psikologi Anak Luar Biasa, Bandung, Refika Aditama.

Soerjono Soekanto, 1981, Pengantar Penelitian Hukum, Jakarta, UI-Press. 
Wahyu wagiman, dkk, 2007, Naskah Akademis dan Rancangan Peraturan Pemerintah Tentang Pemberian Kompensasi dan Resituasi serta Bantuan Bagi Korban, Jakarta, ICW.

Waluyo, 2012, Viktimologi Perlindungan Korban \& Saksi, Jakarta, Sinar Grafika. 
140 | 'Adliya Vol. 12, No. 2, Juni 2018 